OPEN ACCESS

Edited by:

Alexandrina L. Dumitrescu,

Other, Romania

Reviewed by:

Douglas Watt,

School of Medicine, Boston University,

United States

Marcos Lopez,

Fundación Cardiovascular de

Colombia, Colombia

*Correspondence:

Peter Celec

petercelec@gmail.com

Specialty section: This article was submitted to

Oxidant Physiology,

a section of the journal

Frontiers in Physiology

Received: 15 July 2017 Accepted: 04 December 2017 Published: 14 December 2017

Citation:

Tóthová L' and Celec P (2017) Oxidative Stress and Antioxidants in

the Diagnosis and Therapy of

Periodontitis. Front. Physiol. 8:1055.

doi: 10.3389/fphys.2017.01055

\section{Oxidative Stress and Antioxidants in the Diagnosis and Therapy of Periodontitis}

\author{
L'ubomíra Tóthová ${ }^{1,2}$ and Peter Celec ${ }^{1,3,4 *}$ \\ ${ }^{1}$ Faculty of Medicine, Institute of Molecular Biomedicine, Comenius University, Bratislava, Slovakia, ${ }^{2}$ Faculty of Medicine, \\ Institute of Physiology, Comenius University, Bratislava, Slovakia, ${ }^{3}$ Faculty of Medicine, Institute of Pathophysiology, \\ Comenius University, Bratislava, Slovakia, ${ }^{4}$ Department of Molecular Biology, Faculty of Natural Sciences, Comenius \\ University, Bratislava, Slovakia
}

Oxidative stress has been implicated in the pathogenesis of numerous diseases. However, large interventional studies with antioxidants failed to show benefits in the prevention or treatment of cardiovascular diseases, cancer, or diabetes mellitus. Numerous clinical studies have confirmed the association of oxidative stress markers and periodontitis. Technical and biological variability is high for most of the analyzed markers and none of them seems to be optimal for routine clinical use. In a research setting, analysis of a palette of oxidative stress markers is needed to cover lipid peroxidation, protein oxidation, and the antioxidant status. The source of reactive oxygen species and their role in the pathogenesis of periodontitis remains unclear. Interventional experiments indicate that oxidative stress might be more than just a simple consequence of the inflammation. Small studies have confirmed that some antioxidants could have therapeutic value at least as an addition to the standard non-surgical treatment of periodontitis. A clear evidence for the efficiency of antioxidant treatment in large patient cohorts is lacking. Potentially, because lowering of oxidative stress markers might be a secondary effect of anti-inflammatory or antibacterial agents. As the field of research of oxidative stress in periodontitis gains attraction and the number of relevant published papers is increasing a systematic overview of the conducted observational and interventional studies is needed. This review summarizes the currently available literature linking oxidative stress and periodontitis and points toward the potential of adjuvant antioxidant treatment, especially in cases where standard treatment fails to improve the periodontal status.

Keywords: reactive oxygen species, free radicals, antioxidative therapy, systematic review, oral diseases

\section{INTRODUCTION}

Oxidative stress is both, a pathomechanism involved in numerous inflammatory diseases causing damage to lipids, nucleic acids and proteins-oxidative distress, as well as an important physiological process that enables the immune system to cope with microorganisms and intracellular cell signaling-oxidative eustress (Sies et al., 2017). Which edge of the sword is the dominant depends on the delicate balance between the production of reactive oxygen/nitrogen species and the antioxidant capacity of the tissue. The physiological functions of free radicals have 
been neglected for years and so, much more is known about the pathological role of oxidative stress. A variety of free radicals is produced and interacts with a variety of substrates. This leads to a palette of biomarkers that can be used for the assessment of oxidative stress-induced damage (Frijhoff et al., 2015).

Oxidative stress is usually defined as a disbalance of the production of free radicals and antioxidant mechanisms (Kopáni et al., 2006). However, free radicals are not a simple negative byproduct of oxygen metabolism. They are involved in immune responses, liver metabolism, but also in intracellular signaling pathways (Espinosa-Diez et al., 2015). The mechanisms involved in the physiological intracellular role of free radicals include the modulation of cysteine residues of redox-sensitive enzymes and other regulatory proteins (Finkel, 2011; Russell and Cotter, 2015). It has been hypothesized that under physiological conditions even high concentrations of any one primary reactive oxygen or nitrogen species does not lead to oxidative damage, as the cell has preventive and reparative tools to cope with the radical. The reactions of superoxide, nitric oxide, and other primary reactive species are reversible and are ideal for intracellular signaling (Weidinger and Kozlov, 2015). Thus, measuring oxidative stress using any one marker can lead to wrong interpretations. This might include the hope that administration of antioxidants will effectively treat diseases associated with oxidative stress. As recently hypothesized, one of the prototypic oxidative stress diseases-diabetes mellitus might be actually a consequence of deficiency of reactive oxygen species rather than of oxidative damage (Watson, 2014). It should not escape our notice that this proposed mechanism might suggest that antioxidants could increase the risk rather than prevent metabolic diseases.

Periodontitis is an inflammatory disease affecting supporting structures of the teeth leading at the end to loss of alveolar bone and teeth (Kinane et al., 2017). The main causative factor are microorganisms that colonize the subgingival dental plaque inducing an inflammatory host response. The inflammation affects, however, also the surrounding healthy tissue ultimately leading to the destruction of the periodontium (Kinane et al., 2011). Although lipopolysaccharide and proteolytic enzymes are essential in periodontitis, exaggerated inflammatory response, genetic predisposition, smoking, bad oral hygiene, and malnutrition are important in pathogenesis of periodontitis as well (Laine et al., 2012).

The role of oxidative stress in periodontitis has been postulated already decades ago (Shapira et al., 1991; Chapple, 1997). However, the suggested involvement was not clear. Some studies showed that leukocytes from patients with periodontitis are exhausted and have a low oxidation activity (Loesche et al., 1988), other studies pointed toward higher production of free radicals by leukocytes from periodontitis patients (Kimura et al., 1993). The contradictory findings from these studies might be related to the dynamics of the mechanisms during the pathogenesis of the disease, but they might also be explained by the different forms of periodontitis (Biasi et al., 1999).

The term oxidative stress is vague, similarly, antioxidants might affect many processes not directly related to free radical generation or action (Niki, 2016). This makes the interpretation of studies focusing on oxidative stress in periodontitis difficult. A systematic review of these clinical studies and animal experiments might, thus, be needed.

\section{BIOMARKERS OF OXIDATIVE STRESS AND PATHOGENESIS OF PERIODONTITIS}

Surprisingly, many observational studies analyzing oxidative stress in patients with periodontitis had relatively consistent results with higher oxidative stress markers in either saliva or blood and/or decreased antioxidant status in comparison to controls. The summary table of the identified studies can be found in Table 1. One of the largest observational studies has shown that the antioxidant status in blood, analyzed as vitamin $\mathrm{C}$, bilirubin, and calculated total antioxidant capacity was inversely associated with mild and severe periodontitis (Chapple et al., 2007b). The more severe periodontitis, the clearer the association. Additionally, in a subgroup of neversmokers the antioxidants seemed to protect against development of periodontitis. Others smaller studies confirmed these results. Total antioxidant capacity was lower in plasma or serum of patients with chronic periodontitis (Chapple et al., 2002; Brock et al., 2004; Konopka et al., 2007). Similarly, superoxide dismutase activity (Huang et al., 2014) along with catalase and glutathione peroxidase activity (Tonguç et al., 2011) as important contributor to the total antioxidant capacity was found to be lower in periodontitis. In line with these results from blood, in the majority of studies, the antioxidant status was lower also locally-in saliva. The total antioxidant status/potential/capacity is in general the ability of a tissue to resist artificially induced oxidative stress, but studies differ in the analytical approaches. Nevertheless, the local antioxidant capacity was found to be lower in saliva from patients with an aggressive form of periodontitis when compared to chronic periodontitis (Acquier et al., 2017). Patients with chronic periodontitis have lower antioxidant capacity than control patients (Zhang et al., 2015; Ahmadi-Motamayel et al., 2017). Although the total antioxidant capacity is not a specific marker of antioxidant power, uric acid, glutathione peroxidase (Miricescu et al., 2014), and reduced glutathione (Gumus et al., 2009) as specific antioxidants were reported to be significantly lower in saliva of patients with chronic or aggressive periodontitis. On contrary, activities of the major antioxidant enzymes were found to be higher in chronic periodontitis patients in all investigated samples, i.e., plasma, erythrocytes, and in the gingival tissue (Panjamurthy et al., 2005). Similarly, SOD2 and GPX1 genes were overexpressed in the gingiva of chronic periodontitis patients (Duarte et al., 2012). Lactoferrin, myeloperoxidase and interleukin 1 beta were all positively correlated with the clinical markers of periodontal damage (Wei et al., 2004). However, whether such associations of higher antioxidant and pro-inflammatory response are a consequence or cause of severe periodontitis cannot be judged only from observations.

Regarding the analyzed markers of oxidative stress, a comparison of the published studies is complicated, if not impossible due to the huge variability of measured markers. 
TABLE 1 | Observational studies analyzing oxidative stress in periodontitis.

\begin{tabular}{|c|c|c|c|c|c|}
\hline Study design & Sample size & Note & Sample type & Outcome & References \\
\hline $\begin{array}{l}\text { Cross-sectional } \\
\text { study }\end{array}$ & $\begin{array}{l}20 \mathrm{AgP} \text { patients } \\
20 \mathrm{ChP} \text { patients } \\
20 \text { controls }\end{array}$ & - & Saliva & $\begin{array}{l}\uparrow R O S, \text { TBARS with AgP; } \\
\text { TRAP } \downarrow \text { with AgP compared to ChP }\end{array}$ & $\begin{array}{l}\text { Acquier et al., } \\
2017\end{array}$ \\
\hline $\begin{array}{l}\text { Case-control } \\
\text { study } \\
\text { (cross-sectional) }\end{array}$ & $\begin{array}{l}55 \text { ChP patients } \\
55 \text { healthy controls }\end{array}$ & - & $\begin{array}{l}\text { Serum } \\
\text { Saliva }\end{array}$ & $\begin{array}{l}\downarrow \text { TAC in serum and saliva; } \\
\uparrow \mathrm{MDA} \text { increased in serum and } \\
\text { saliva vs. controls }\end{array}$ & $\begin{array}{l}\text { Ahmadi- } \\
\text { Motamayel } \\
\text { et al., } 2017\end{array}$ \\
\hline $\begin{array}{l}\text { Comparative study } \\
\text { (cross-sectional) }\end{array}$ & $\begin{array}{l}20 \text { T2DM patients with periodontitis } \\
20 \text { T2DM patients PH } \\
20 \text { SH patients with periodontitis }\end{array}$ & T2DM & Plasma & $\begin{array}{l}\downarrow \text { plasma small molecule antioxidant capacity } \\
\uparrow \text { PC in T2DM with periodontitis vs. PH T2DM } \\
\text { patients }\end{array}$ & $\begin{array}{l}\text { Allen et al., } \\
2011\end{array}$ \\
\hline $\begin{array}{l}\text { Case-control } \\
\text { study }\end{array}$ & $\begin{array}{l}15 \mathrm{PH}+\text { normal weight } \\
15 \text { gingivitis + normal weight } \\
15 \mathrm{ChP}+\text { normal weight } \\
15 \mathrm{PH}+\text { obese } \\
18 \text { gingivitis + obese } \\
15 \mathrm{ChP}+\text { obese }\end{array}$ & Obesity & GCF & $\uparrow \mathrm{MDA}, \mathrm{PC}$ and $\downarrow \mathrm{TAC}$ in ChP + obese group & $\begin{array}{l}\text { Atabay et al., } \\
2017\end{array}$ \\
\hline $\begin{array}{l}\text { Cross-sectional } \\
\text { study }\end{array}$ & $\begin{array}{l}32 \mathrm{ChP} \text { post-menopausal women } \\
31 \mathrm{ChP} \text { pre-menopausal } \\
25 \mathrm{PH} \text { post-menopausal women } \\
26 \mathrm{PH} \text { pre-menopausal women }\end{array}$ & Menopause & $\begin{array}{l}\text { Serum } \\
\text { GCF }\end{array}$ & $\begin{array}{l}\downarrow \text { TAC, SOD activity in post-menopausal women } \\
\text { with ChP in serum and GCF }\end{array}$ & $\begin{array}{l}\text { Baltacioglu } \\
\text { et al., } 2006\end{array}$ \\
\hline $\begin{array}{l}\text { Cross-sectional } \\
\text { study }\end{array}$ & $20 \mathrm{ChP}$ patients 20 healthy controls & - & $\begin{array}{l}\text { Serum } \\
\text { Saliva } \\
\text { GCF }\end{array}$ & $\begin{array}{l}\downarrow \text { TAC in GCF and plasma in ChP vs. control; } \\
\downarrow \text { TAC in saliva in ChP vs. control }\end{array}$ & $\begin{array}{l}\text { Brock et al., } \\
2004\end{array}$ \\
\hline $\begin{array}{l}\text { Cross-sectional } \\
\text { study }\end{array}$ & $\begin{array}{l}32 \mathrm{ChP} \text { patients } \\
32 \mathrm{PH} \text { control }\end{array}$ & - & $\begin{array}{l}\text { Saliva } \\
\text { Gingival tissue }\end{array}$ & $\begin{array}{l}\uparrow 8-\mathrm{OHdG} \text { and mtDNA deletions in ChP group vs. } \\
\text { control }\end{array}$ & $\begin{array}{l}\text { Canakci et al., } \\
2009\end{array}$ \\
\hline $\begin{array}{l}\text { Cross-sectional } \\
\text { study }\end{array}$ & $\begin{array}{l}30 \mathrm{ChP} \text { patients } \\
30 \mathrm{PH} \text { control }\end{array}$ & - & $\begin{array}{l}\text { Blood } \\
\text { Gingival tissue }\end{array}$ & $\uparrow$ mtDNA deletion in ChP group vs. control & $\begin{array}{l}\text { Canakci et al., } \\
2006\end{array}$ \\
\hline $\begin{array}{l}\text { Cross-sectional } \\
\text { study }\end{array}$ & $\begin{array}{l}10 \text { preeclampsia } \mathrm{ChP} \\
10 \text { preeclampsia } \mathrm{PH} \\
10 \text { normotensive } \mathrm{ChP} \\
10 \text { normotensive } \mathrm{PH}\end{array}$ & Preeclampsia & $\begin{array}{l}\text { Serum } \\
\text { Saliva } \\
\text { GCF }\end{array}$ & $\begin{array}{l}\downarrow \text { TAC in ChP women with preeclampsia (GCF, } \\
\text { serum, saliva); } \\
\downarrow \text { SOD and GPx activities decreased in ChP } \\
\text { women with preeclampsia (GCF and serum); } \\
\uparrow \text { MDA in ChP preeclamptic women (GCF, serum) }\end{array}$ & $\begin{array}{l}\text { Canakci et al., } \\
2007\end{array}$ \\
\hline $\begin{array}{l}\text { Cross-sectional } \\
\text { study }\end{array}$ & $\begin{array}{l}31 \text { pre-menopausal } \\
31 \text { peri-menopausal } \\
31 \text { post-menopausal ChP women }\end{array}$ & Menopause & $\begin{array}{l}\text { GCF } \\
\text { Gingival tissue }\end{array}$ & $\begin{array}{l}\uparrow 8-\mathrm{OHdG} \text { in ChP post-menopausal women in } \\
\text { GCF and gingival tissue }\end{array}$ & $\begin{array}{l}\text { Chandra et al., } \\
2017\end{array}$ \\
\hline $\begin{array}{l}\text { Cross-sectional } \\
\text { study }\end{array}$ & $\begin{array}{l}10 \mathrm{ChP} \text { patients } \\
10 \mathrm{PH} \text { control }\end{array}$ & - & $\begin{array}{l}\text { Plasma } \\
\text { GCF }\end{array}$ & $\begin{array}{l}\downarrow \text { TAC in GCF and plasma in ChP vs. control; } \\
\downarrow \text { GSH and GSSG in GCF in ChP }\end{array}$ & $\begin{array}{l}\text { Chapple et al., } \\
2002\end{array}$ \\
\hline
\end{tabular}


TABLE 1 | Continued

\begin{tabular}{|c|c|c|c|c|c|}
\hline Study design & Sample size & Note & Sample type & Outcome & References \\
\hline $\begin{array}{l}\text { Observational } \\
\text { correlational study }\end{array}$ & $\begin{array}{l}11,480 \text { participants; } \\
1,567 \text { with mild periodontitis } \\
609 \text { with severe periodontitis }\end{array}$ & - & Serum & $\begin{array}{l}\downarrow \text { vitamin C, bilirubin and TAC (calculated) in mild } \\
\text { or severe periodontitis }\end{array}$ & $\begin{array}{l}\text { Chapple et al., } \\
\text { 2007b }\end{array}$ \\
\hline $\begin{array}{l}\text { Cross-sectional } \\
\text { study }\end{array}$ & $\begin{array}{l}17 \text { periodontitis patients } \\
20 \text { healthy controls }\end{array}$ & - & Saliva & $\downarrow$ TAC in periodontitis & $\begin{array}{l}\text { Diab-Ladki } \\
\text { et al., } 2003\end{array}$ \\
\hline $\begin{array}{l}\text { Cross-sectional } \\
\text { study }\end{array}$ & $\begin{array}{l}12 \mathrm{SH} \text { and } \mathrm{PH} \text { controls } \\
15 \mathrm{SH} \text { and ChP patients } \\
8 \text { well-controlled T2DM patients with } \\
\text { ChP } \\
14 \text { poor-controlled T2DM patients } \\
\text { with ChP }\end{array}$ & T2DM & Gingival tissue & $\begin{array}{l}\text { Peroxiredoxin } 1 \text { and GPX1 overexpressed in ChP; } \\
\text { Peroxiredoxin } 2 \text { and SOD2 up-regulated } \\
\text { especially in poor-controlled T2DM with ChP }\end{array}$ & $\begin{array}{l}\text { Duarte et al., } \\
2012\end{array}$ \\
\hline $\begin{array}{l}\text { Cross-sectional } \\
\text { study }\end{array}$ & $\begin{array}{l}20 \mathrm{ChP} \text { patients with RA } \\
20 \mathrm{PH} \text { patients with } \mathrm{RA} \\
20 \mathrm{ChP} \text { patients SH } \\
20 \mathrm{SH} \text { and } \mathrm{PH} \text { controls }\end{array}$ & $\begin{array}{l}\text { Rheumatoid } \\
\text { arthritis }\end{array}$ & $\begin{array}{l}\text { Serum } \\
\text { GCF }\end{array}$ & $\begin{array}{l}\uparrow \text { TOS in GCF of ChP and RA ChP groups (no } \\
\text { difference for TOS and OSI in serum) }\end{array}$ & $\begin{array}{l}\text { Esen et al., } \\
2012\end{array}$ \\
\hline $\begin{array}{l}\text { Cross-sectional } \\
\text { study }\end{array}$ & $\begin{array}{l}24 \mathrm{ChP} \text { with depression } \\
23 \mathrm{ChP} \text { without depression }\end{array}$ & Depression & Plasma & $\begin{array}{l}\uparrow \text { nitric oxide metabolites, lipid peroxides, AOPP } \\
\text { and TRAP in ChP with depression }\end{array}$ & $\begin{array}{l}\text { Gomes et al., } \\
2017\end{array}$ \\
\hline $\begin{array}{l}\text { Cross-sectional } \\
\text { study }\end{array}$ & $\begin{array}{l}16 \text { T1DM with periodontitis } \\
25 \text { T2DM with periodontitis } \\
24 \text { SH with periodontitis }\end{array}$ & $\begin{array}{l}\text { T1DM } \\
\text { T2DM }\end{array}$ & Saliva & $\downarrow$ GSH and $\downarrow$ GSSG in the patients with T1DM & $\begin{array}{l}\text { Gumus et al., } \\
2009\end{array}$ \\
\hline $\begin{array}{l}\text { Case-control } \\
\text { study }\end{array}$ & $\begin{array}{l}115 \mathrm{P} \text { women ( } 6 \text { month postpartum } \\
\text { follow-up) } \\
72 \text { non-P women }\end{array}$ & Pregnancy & Saliva & $\begin{array}{l}\uparrow 8 \text {-OHdG in PW; } \\
\downarrow \text { GPx decreased in PW; } \\
\downarrow \text { TBARS postpartum vs. non-pregnant women }\end{array}$ & $\begin{array}{l}\text { Gümüş et al., } \\
2015\end{array}$ \\
\hline Prospective study & $\begin{array}{l}218 \mathrm{P} \text { women } \\
459 \mathrm{P} \text { women with mild periodontitis } \\
114 \mathrm{P} \text { women with moderate-severe } \\
\text { periodontitis }\end{array}$ & Pregnancy & Serum & $\begin{array}{l}\uparrow 8 \text {-isoprostane in PW with moderate-severe } \\
\text { periodontitis }\end{array}$ & $\begin{array}{l}\text { Hickman et al., } \\
2011\end{array}$ \\
\hline $\begin{array}{l}\text { Cross-sectional } \\
\text { Study }\end{array}$ & $\begin{array}{l}55 \text { patients with DS } \\
74 \text { patients with mental retardation } \\
88 \text { healthy controls }\end{array}$ & $\begin{array}{l}\text { Down Syndrome } \\
\text { Mental retardation }\end{array}$ & Whole blood & $\begin{array}{l}\uparrow \text { oxidative burst activity of blood (monocytes and } \\
\text { granulocytes) in DS patients with decreased } \\
\text { periodontal health }\end{array}$ & $\begin{array}{l}\text { Khocht et al., } \\
2014\end{array}$ \\
\hline $\begin{array}{l}\text { Cross-sectional } \\
\text { study }\end{array}$ & $\begin{array}{l}26 \text { AgP patients } \\
30 \text { ChP patients } \\
25 \text { healthy controls }\end{array}$ & - & $\begin{array}{l}\text { Gingival blood } \\
\text { Peripheral blood }\end{array}$ & $\begin{array}{l}\uparrow 8-\mathrm{OHdG} \text { in gingival blood of ChP and AgP } \\
\text { patients; } \\
\downarrow \text { TAC in gingival blood of ChP patients; } \\
\downarrow \text { TAC in peripheral blood of both groups }\end{array}$ & $\begin{array}{l}\text { Konopka et al., } \\
2007\end{array}$ \\
\hline $\begin{array}{l}\text { Cross-sectional } \\
\text { study }\end{array}$ & 1,258 old men & Old age & Serum & $\begin{array}{l}\downarrow \text { beta-cryptoxanthin and beta-carotene with } \\
\text { decreased periodontal health of old men }\end{array}$ & $\begin{array}{l}\text { Linden et al., } \\
2009\end{array}$ \\
\hline $\begin{array}{l}\text { Cross-sectional } \\
\text { study }\end{array}$ & $\begin{array}{l}356 \text { periodontitis patients } \\
207 \mathrm{PH} \text { controls }\end{array}$ & - & Plasma & $\begin{array}{l}\uparrow \text { reactive oxygen metabolites and shorter } \\
\text { leukocyte telomere length in ChP }\end{array}$ & $\begin{array}{l}\text { Masi et al., } \\
2011\end{array}$ \\
\hline $\begin{array}{l}\text { Cross-sectional } \\
\text { Correlational study }\end{array}$ & $\begin{array}{l}20 \mathrm{ChP} \text { patients } \\
20 \mathrm{PH} \text { controls }\end{array}$ & - & Saliva & $\begin{array}{l}\uparrow 8-\mathrm{OHdG}, \mathrm{MDA} \text { in ChP; } \\
\downarrow \text { uric acid, GPx activities and TAC in ChP } \\
\text { (correlation with bone loss markers) }\end{array}$ & $\begin{array}{l}\text { Miricescu et al., } \\
2014\end{array}$ \\
\hline $\begin{array}{l}\text { Cross-sectional } \\
\text { study }\end{array}$ & $\begin{array}{l}10 \mathrm{~T} 2 \mathrm{DM} \text { patients } \mathrm{PH} \\
8 \mathrm{SH} \text { controls }\end{array}$ & T2DM & Periodontal tissue & $\uparrow$ MDA, $\downarrow$ GSH in periodontal tissue of T2DM & $\begin{array}{l}\text { Monea et al., } \\
2014\end{array}$ \\
\hline $\begin{array}{l}\text { Cross-sectional } \\
\text { study }\end{array}$ & $\begin{array}{l}24 \text { ChP patients with ACS } \\
24 \text { patients } \mathrm{PH} \text { with ACS } \\
24 \text { ChP patients without ACS } \\
24 \text { controls } \mathrm{PH} \text { without ACS }\end{array}$ & $\begin{array}{l}\text { Acute coronary } \\
\text { syndrome }\end{array}$ & Saliva & $\begin{array}{l}\uparrow 8-\mathrm{OHdG}, \mathrm{MDA} \text {, and PC in patients (correlation } \\
\text { with periodontal and cardiovascular markers) }\end{array}$ & $\begin{array}{l}\text { Nguyen et al., } \\
2016\end{array}$ \\
\hline
\end{tabular}


TABLE 1 | Continued

\begin{tabular}{|c|c|c|c|c|c|}
\hline Study design & Sample size & Note & Sample type & Outcome & References \\
\hline $\begin{array}{l}\text { Cross-sectional } \\
\text { study }\end{array}$ & $\begin{array}{l}25 \text { ChP patients } \\
25 \text { healthy controls }\end{array}$ & - & $\begin{array}{l}\text { Plasma } \\
\text { Gingival tissue } \\
\text { Erythrocytes }\end{array}$ & $\begin{array}{l}\uparrow \text { TBARS in ChP; } \\
\uparrow \mathrm{SOD}, \mathrm{CAT}, \mathrm{GPx} \text { activities in ChP; } \\
\downarrow \text { vitamins } \mathrm{E}, \mathrm{C} \text { and GSH in ChP }\end{array}$ & $\begin{array}{l}\text { Panjamurthy } \\
\text { et al., } 2005\end{array}$ \\
\hline $\begin{array}{l}\text { Cross-sectional } \\
\text { study }\end{array}$ & $\begin{array}{l}29 \text { ChP patients } \\
20 \text { healthy controls }\end{array}$ & - & Saliva & $\uparrow 8-\mathrm{OHdG}$ in $\mathrm{ChP}$ (correlation with $P$. gingivalis) & $\begin{array}{l}\text { Sawamoto } \\
\text { et al., } 2005\end{array}$ \\
\hline $\begin{array}{l}\text { Cross-sectional } \\
\text { cohort study }\end{array}$ & $\begin{array}{l}46 \text { severe periodontitis patients } \\
37 \text { moderate periodontitis patients } \\
46 \text { mild periodontitis and healthy }\end{array}$ & - & Saliva & $\begin{array}{l}\uparrow P C \text { increased in severe periodontitis; } \\
\downarrow \text { urate and FRAP in severe periodontitis }\end{array}$ & $\begin{array}{l}\text { Sculley and } \\
\text { Langley-Evans, } \\
2003\end{array}$ \\
\hline $\begin{array}{l}\text { Cross-sectional } \\
\text { study }\end{array}$ & $\begin{array}{l}20 \mathrm{ChP} \text { patients with RA } \\
20 \mathrm{PH} \text { patients with RA } \\
20 \mathrm{ChP} \text { patients without RA } \\
20 \mathrm{PH} \text { SH controls }\end{array}$ & $\begin{array}{l}\text { Rheumatoid } \\
\text { arthritis }\end{array}$ & Serum & $\uparrow$ OSI and prolidase in ChP patients with RA & $\begin{array}{l}\text { Sezer et al., } \\
2013\end{array}$ \\
\hline $\begin{array}{l}\text { Cross-sectional } \\
\text { study }\end{array}$ & $\begin{array}{l}20 \mathrm{ChP} \text { patients with PS } \\
20 \mathrm{PH} \text { patients with PS } \\
20 \mathrm{ChP} \text { patients with PsA } \\
20 \mathrm{PH} \text { patients with PsA } \\
20 \mathrm{ChP} \text { SH patients } \\
20 \mathrm{PH} \mathrm{SH} \mathrm{controls}\end{array}$ & $\begin{array}{l}\text { Psoriasis } \\
\text { Psoriatic } \\
\text { arthritis }\end{array}$ & Serum & $\begin{array}{l}\uparrow \text { OSI (irrespective of periodontitis) in patients } \\
\text { groups; (PS and PsA showed no effect on clinical } \\
\text { parameters in ChP patients) }\end{array}$ & $\begin{array}{l}\text { Sezer et al., } \\
2016\end{array}$ \\
\hline $\begin{array}{l}\text { Cross-sectional } \\
\text { study }\end{array}$ & 4,717 participants & $\begin{array}{l}\text { Diabetes } \\
\text { mellitus } \\
\text { Hypertension }\end{array}$ & Serum & $\begin{array}{l}\text { Periodontitis with highest 8-isoprostane quartile } \\
\text { associated with } \uparrow \mathrm{CRP}\end{array}$ & $\begin{array}{l}\text { Singer et al., } \\
2015\end{array}$ \\
\hline $\begin{array}{l}\text { Cross-sectional } \\
\text { correlational study }\end{array}$ & $\begin{array}{l}29 \text { severe periodontitis } \\
77 \text { moderate periodontitis } \\
96 \text { mild periodontitis and healthy }\end{array}$ & $\begin{array}{l}\text { Diabetes } \\
\text { mellitus } \\
\text { Hypertension }\end{array}$ & Serum & $\uparrow R O M$ in patients with worst periodontal status & $\begin{array}{l}\text { Tamaki et al., } \\
2014 b\end{array}$ \\
\hline $\begin{array}{l}\text { Cross-sectional } \\
\text { study }\end{array}$ & $\begin{array}{l}25 \text { severe periodontitis } \\
43 \text { moderate periodontitis } \\
92 \text { mild periodontitis and healthy }\end{array}$ & $\begin{array}{l}\text { Diabetes } \\
\text { mellitus } \\
\text { Hypertension }\end{array}$ & Saliva & $\begin{array}{l}\text { Superoxide and hydroxyl radical scavenging } \\
\text { activities associated with periodontitis }\end{array}$ & $\begin{array}{l}\text { Tamaki et al., } \\
2015\end{array}$ \\
\hline $\begin{array}{l}\text { Cross-sectional } \\
\text { study }\end{array}$ & 39 patients with periodontitis & - & Saliva & $\begin{array}{l}\downarrow \text { antioxidant concentrations related to } \\
\text { periodontal status }\end{array}$ & $\begin{array}{l}\text { Tartaglia et al., } \\
2017\end{array}$ \\
\hline $\begin{array}{l}\text { Cross-sectional } \\
\text { study }\end{array}$ & $\begin{array}{l}23 \text { smokers with ChP } \\
23 \text { former smokers with ChP } \\
19 \text { non-smokers with ChP } \\
20 \mathrm{PH} \text { non-smokers controls }\end{array}$ & Smoking & $\begin{array}{l}\text { Serum } \\
\text { Gingival tissue }\end{array}$ & $\begin{array}{l}\uparrow \mathrm{MDA} \text { in serum and gingival tissue in smoking } \\
\text { ChP patients groups; } \\
\downarrow \text { SOD, CAT and GPx in ChP groups }\end{array}$ & $\begin{array}{l}\text { Tonguç et al., } \\
2011\end{array}$ \\
\hline $\begin{array}{l}\text { Cross-sectional } \\
\text { study }\end{array}$ & $\begin{array}{l}100 \text { ChP patients } \\
50 \text { healthy controls }\end{array}$ & - & Saliva & $\begin{array}{l}\uparrow 8-\mathrm{OHdG} \text { and human neutrophil } \\
\text { elastase/alpha1-proteinase inhibitor in ChP }\end{array}$ & $\begin{array}{l}\text { Villa-Correa } \\
\text { et al., } 2015\end{array}$ \\
\hline $\begin{array}{l}\text { Cross-sectional } \\
\text { study }\end{array}$ & $\begin{array}{l}19 \text { patients with periodontitis } \\
8 \text { healthy controls }\end{array}$ & - & GCF & $\begin{array}{l}\uparrow \text { GPx, lactoferrin, myeloperoxidase and IL-1beta } \\
\text { in periodontal tissues (correlation with clinical } \\
\text { periodontal markers) }\end{array}$ & Wei et al., 2004 \\
\hline $\begin{array}{l}\text { Cross-sectional } \\
\text { study }\end{array}$ & $\begin{array}{l}31 \text { smokers } \\
90 \text { non-smokers }\end{array}$ & Smoking & Saliva & $\begin{array}{l}\uparrow \text { 8-epi-PGF(2alpha) with periodontal status and } \\
\text { smoking; Smoking } \uparrow \text { TXB(2) and PGF(2alphas) } \\
\text { and } \\
\downarrow \text { 6-oxo-PGF(1alpha) }\end{array}$ & $\begin{array}{l}\text { Wolfram et al., } \\
2006\end{array}$ \\
\hline $\begin{array}{l}\text { Cross-sectional } \\
\text { study }\end{array}$ & $\begin{array}{l}58 \text { ChP patients } \\
42 \text { AgP patients } \\
60 \text { healthy controls }\end{array}$ & - & $\begin{array}{l}\text { Saliva } \\
\text { Buccal mucosa }\end{array}$ & $\begin{array}{l}\uparrow \text { micronuclei and nuclear abnormalities, as well } \\
\text { as } 8-\mathrm{OHdG} \text { in both periodontitis groups }\end{array}$ & $\begin{array}{l}\text { Zamora-Perez } \\
\text { et al., } 2015\end{array}$ \\
\hline $\begin{array}{l}\text { Cross-sectional } \\
\text { study }\end{array}$ & $\begin{array}{l}45 \text { severe periodontitis patients } \\
37 \text { healthy controls }\end{array}$ & - & Saliva & $\downarrow$ TAC in periodontitis (TOS no difference) & $\begin{array}{l}\text { Zhang et al., } \\
2015\end{array}$ \\
\hline
\end{tabular}

ChP, chronic periodontitis; AgP, aggressive periodontitis; SH, systematically healthy; PH, periodontal healthy; T1DM, type 1 diabetes mellitus; T2DM, type 2 diabetes mellitus; PS, psoriasis; PSA, psoriatic arthritis; DS, Down syndrome; PW, pregnant woman; RA, Rheumatoid arthritis; ACS, Acute coronary syndrome; GCF, gingival crevicular fluid; TAC, total antioxidant capacity; TBARS, thiobarbituric acid reacting substances; 8-HOdG, 8-hydroxydeoxyguanosine; GPX, glutathione peroxidase; GSH, reduced glutathione; GSSG, oxidized glutathione; PC, protein carbonyls; MDA, malondialdehyde; TOS, total oxidant status; SOD, superoxid dismutase; OSI, oxidative stress index; IL-1beta, interleukin 1beta; ROM, reactive oxygen metabolites; ROS, reactive oxygen species; FRAP, ferric reducing antioxidant power; 4-HNE, 4-hydroxy-2-nonenal; CAT, catalase; CRP, C-reactive protein; AOPP, advanced oxidation protein products; TRAP, total radical-trapping antioxidant potential; MPO, myeloperoxidase; mtDNA, mitochondrial DNA. 
Malondialdehyde, 8-hydroxydeoxyguanosine (Konopka et al., 2007; Almerich-Silla et al., 2015), protein carbonyls (Nguyen et al., 2016; Atabay et al., 2017), thiobarbituric acid reacting substances (Borges et al., 2007), nitric oxide, advanced oxidation protein products, lipid peroxidation products (Gomes et al., 2017), 8-isprostanes (Hickman et al., 2011) were all higher in patients with periodontitis. The most commonly measured markers of oxidative stress seem to be malondialdehyde and thiobarbituric acid reacting substances pointing toward oxidative damage of lipids, especially, lipid membranes. Lipid peroxidation was higher in saliva (Tothova et al., 2013), serum (Tonguç et al., 2011), and in the gingival tissue (Panjamurthy et al., 2005) of patients with chronic or aggressive periodontitis. Correlational studies confirmed a positive association of these markers with periodontal status scores (Chapple et al., 2007b; Tamaki et al., 2014b). The less commonly measured markers related to oxidative damage as mitochondrial DNA (Canakci et al., 2006), micronuclei and nuclear abnormalities (ZamoraPerez et al., 2015), as well as a leukocyte telomere length shortening (Masi et al., 2011) were all higher in periodontitis as well.

Oxidative stress was found to be involved in the pathogenesis of many diseases besides periodontitis. Virtually, almost all inflammatory diseases lead to increased oxidative stress. This in turn can trigger more damage to the tissues, not excluding the gingival tissue and, thus, worsening periodontitis. There are several studies describing oxidative stress in systemic diseases with regard to the periodontal status. Nguyen et al. (2016) investigated patients with the acute coronary syndrome with or without chronic periodontitis, patients with periodontitis and healthy controls. Lipid, protein, and DNA oxidation markers were higher in periodontitis than in the control group (Nguyen et al., 2016). Another study with rheumatoid arthritis and chronic periodontitis confirmed higher oxidative stress markers in plasma and lower antioxidant capacity in both groups when compared to healthy control. However, if both comorbidities were present, there was no further enhancement of oxidative stress (Sezer et al., 2013).

Taken together, observational cross-sectional studies confirmed the association of oxidative stress and periodontitis. Higher oxidative stress and lower antioxidant status can be detected in plasma, saliva as well as in the gingival crevicular fluid of patients with various clinical forms of periodontitis. These findings support the use of body fluids, but especially the non-invasive diagnostic fluid saliva, as suitable sample types for diagnostics or monitoring the course of periodontitis. Current data do not support the use of a single oxidative stress marker. It is likely that a set of markers covering both, oxidative damage and antioxidative status, will be needed. The low specificity of oxidative stress markers calls for caution when interpreting the results even if more than one marker is used. The inter-individual and intra-individual variability of the analyzed markers is very high. This prevents their use at the level of individual diagnostics. The overview of the published observational studies shows the enormous heterogeneity of the patient populations as well as the used analytical tools. In a metaanalysis focusing on systematic oxidative stress, it was shown that higher malondialdehyde and nitric oxide as well as lower total antioxidant capacity of plasma/serum characterize patients with periodontitis in comparison to controls (Liu et al., 2014). Based on our overview, taken into account systemic and local oral biomarkers of oxidative stress, it is clear that there is a need for both, the use of a wider palette of markers to analyze oxidative stress and its causes in more detail, and the introduction of new biomarkers with a better sensitivity/specificity profile in specific subgroups of patients. Of special importance is the small sample size in most studies. A collaborative effort with a multi-center recruitment of patients and a standardized consensus protocol in the pre-analytical and analytical phase is highly needed.

\section{OXIDATIVE STRESS AND TREATMENT OF PERIODONTITIS}

The implication of oxidative stress in the pathogenesis of cardiovascular diseases and cancer as the major causes of death in the combination with the widespread availability of dietary antioxidants started a hype that was supported by the hypothesis that aging is caused by oxidative stress (Harman, 1956; Finkel and Holbrook, 2000). However, the hype was quickly over as large clinical studies revealed that antioxidants or at least antioxidant vitamins were not able to prevent any of the diseases of aging (Coulter et al., 2006; Sesso et al., 2008; Myung et al., 2013). Some studies even revealed a slight but increased risk in patients taking antioxidants in preeclampsia (Rumbold et al., 2006) and lung cancer (Alpha-Tocopherol, 1994). One metaanalysis showed that taking antioxidant may even increase the all-cause mortality by $5 \%$ (Bjelakovic et al., 2007). This might be related to the terminological and mechanistic confusion about antioxidants, which might have a very indirect effect on the production or effects of reactive oxygen species. In an era of evidence-based medicine the clear conclusion is that antioxidant dietary supplements should undergo clinical evaluation before marketing similarly to other medicinal drugs (Bjelakovic et al., 2012). Recent mechanistic experiments shed light on the details how antioxidants may stimulate tumor growth (Sayin et al., 2014) or increase the risk of metastasis (Piskounova et al., 2015). Antioxidants are highly variable in their mechanism and structure. Diseases and patients vary even more. So, negative results from oncology or cardiology should not be generalized to other diseases including periodontitis. It is very likely that the role of oxidative stress changes during disease progression and, thus, the potential antioxidant treatment affecting not only oxidative damage but also the inflammatory process might have different affects at various stages of the complex pathogenesis. The issue of antioxidants that mostly do not affect free radicals and their action in vivo, but rather interfere with variable cellular signaling pathways has been reviewed in a recently published paper (Azzi, 2017).

Many published studies have analyzed the effects of periodontitis treatment on oxidative stress (Table 2). Studies of special interest are those with covariates or comorbidities that were taken into account. A trial by Guentsch et al. (2008) examined healthy subjects and patients with periodontitis further 
TABLE 2 | Interventional studies analyzing the effect of periodontitis on oxidative stress.

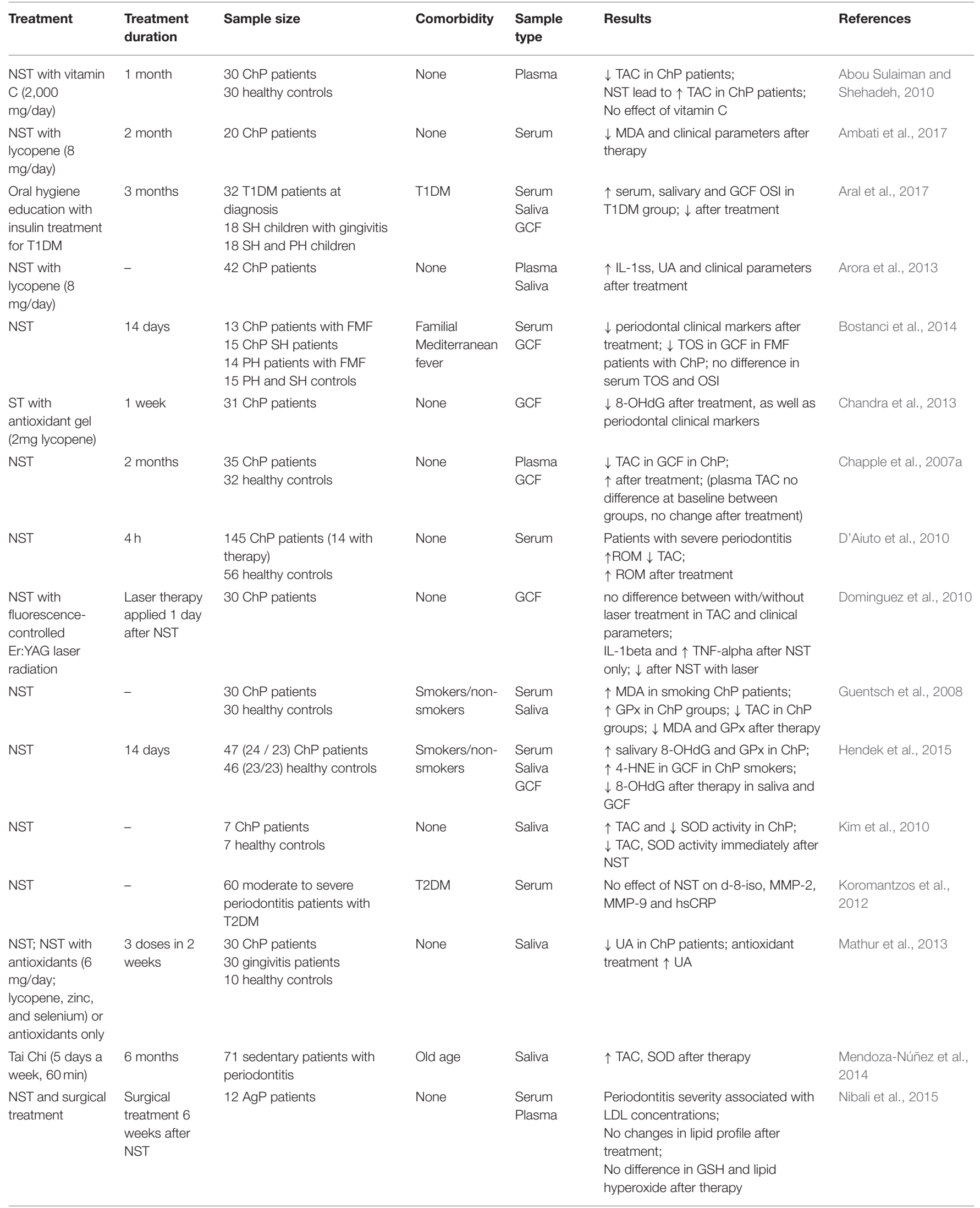


TABLE 2 | Continued

\begin{tabular}{|c|c|c|c|c|c|c|}
\hline Treatment & $\begin{array}{l}\text { Treatment } \\
\text { duration }\end{array}$ & Sample size & Comorbidity & $\begin{array}{l}\text { Sample } \\
\text { type }\end{array}$ & Results & References \\
\hline $\begin{array}{l}\text { NST or oral } \\
\text { hygiene } \\
\text { instructions }\end{array}$ & $\begin{array}{l}2 \text { visits within } \\
7 \text { days }\end{array}$ & $\begin{array}{l}42 \text { ChP patients } \\
21 \text { healthy controls }\end{array}$ & None & Saliva & $\begin{array}{l}\text { NST lead to } \uparrow \text { TAC, ALB, UA, GPx } \\
\text { and } \downarrow \text { SOD; (no effect of oral hygiene } \\
\text { instructed therapy was found) }\end{array}$ & Novakovic et al., 2014 \\
\hline NST & - & $\begin{array}{l}25 \text { severe ChP patients } \\
26 \text { healthy controls }\end{array}$ & None & $\begin{array}{l}\text { Serum } \\
\text { Saliva }\end{array}$ & $\begin{array}{l}\text { Salivary } 8-\mathrm{OHdG} \uparrow \text { before treatment } \\
\text { in ChP group; } \downarrow \text { after NST } \\
\uparrow \text { salivary MDA and serum 4-HNE } \\
\text { in ChP patients; NST had no effect }\end{array}$ & Onder et al., 2017 \\
\hline $\begin{array}{l}\text { NST with } \\
\text { Coenzyme Q10; } \\
\text { NST with tea } \\
\text { tree oil gel or } \\
\text { placebo }\end{array}$ & 7 days & $\begin{array}{l}15 \text { ChP patients } \\
\text { (moderate to severe) }\end{array}$ & None & - & $\begin{array}{l}\text { Both antioxidant treatment } \\
\text { procedures effective in } \downarrow \text { clinical } \\
\text { markers of ChP (PI, GI, PPD and CAL) }\end{array}$ & Raut and Sethi, 2016 \\
\hline $\begin{array}{l}\text { NST and oral } \\
\text { hygiene } \\
\text { instructions }\end{array}$ & 2-4 months & $\begin{array}{l}29 \text { ChP patients } \\
20 \text { healthy controls }\end{array}$ & None & Saliva & $\begin{array}{l}\uparrow 8-\mathrm{OHdG} \text { in } \mathrm{ChP} \text { patients before } \\
\text { therapy; } \downarrow 8-\mathrm{OHdG} \text { and } P \text {. gingivalis } \\
\text { after treatment, as well as periodontal } \\
\text { clinical markers }\end{array}$ & Sawamoto et al., 2005 \\
\hline NST & - & $\begin{array}{l}8 \mathrm{ChP} \text { patients } \\
8 \text { healthy controls }\end{array}$ & None & $\begin{array}{l}\text { Platelet } \\
\text { suspension }\end{array}$ & $\begin{array}{l}\downarrow \text { periodontal clinical parameters and } \\
\text { CRP after therapy, as well as } \\
\uparrow \text { cGMP and SOD activity }\end{array}$ & Siqueira et al., 2013 \\
\hline $\begin{array}{l}\text { Surgical } \\
\text { treatment with } \\
\text { taurine ( } 500 \\
\text { mg/day) }\end{array}$ & 15 days & $10 \mathrm{ChP}$ patients & None & $\begin{array}{l}\text { Plasma } \\
\text { Gingival } \\
\text { tissue }\end{array}$ & $\begin{array}{l}\downarrow \text { TBARS, GPx in plasma and gingival } \\
\text { tissue; } \uparrow \text { GSH and } \downarrow \text { periodontal } \\
\text { clinical parameters after therapy }\end{array}$ & $\begin{array}{l}\text { Sree and Sethupathy, } \\
2014\end{array}$ \\
\hline NST & - & $\begin{array}{l}78 \text { ChP patients } \\
17 \text { healthy controls }\end{array}$ & None & Saliva & $\begin{array}{l}\uparrow 8-O H d G \text { in } \mathrm{ChP} \text { patients before } \\
\text { therapy; } \downarrow \text { 8-OHdG and periodontal } \\
\text { clinical markers after therapy }\end{array}$ & Takane et al., 2002 \\
\hline NST & - & $\begin{array}{l}22 \text { ChP patients } \\
22 \text { healthy controls }\end{array}$ & None & Plasma & $\begin{array}{l}\uparrow \text { oxidative index, oxidized LDL and } \\
\text { CRP in ChP; } \downarrow \text { of these parameters } \\
\text { after treatment }\end{array}$ & Tamaki et al., 2011 \\
\hline NST & - & $\begin{array}{l}25 \text { ChP patients } \\
25 \text { patients with gingivitis } \\
25 \text { healthy controls }\end{array}$ & None & Serum & $\begin{array}{l}\downarrow \text { serum TAC and CAT in both groups } \\
\text { of patients; TAC } \uparrow \text { in ChP patients } \\
\text { after therapy (no treatment effect on } \\
\text { CAT) }\end{array}$ & Thomas et al., 2014 \\
\hline NST & $\begin{array}{l}4 \text { visits within } \\
14 \text { days }\end{array}$ & $\begin{array}{l}30(15 / 15) \text { ChP patients } \\
10 \text { healthy controls }\end{array}$ & $\begin{array}{l}\text { Smokers/non- } \\
\text { smokers }\end{array}$ & GCF & $\begin{array}{l}\uparrow I \mathrm{~L}-1 \text { beta in ChP patients; } \\
\downarrow \mathrm{IL}-1 \text { beta after NST irrespective of } \\
\text { smoking; } \\
\text { (no difference in TAC and TOS before } \\
\text { or after treatment between groups) }\end{array}$ & Toker et al., 2012 \\
\hline NST & 2 weeks & $\begin{array}{l}25 \mathrm{ChP} \text { patients with MS } \\
25 \mathrm{ChP} \text { SH patients }\end{array}$ & $\begin{array}{l}\text { Metabolic } \\
\text { syndrome }\end{array}$ & $\begin{array}{l}\text { Serum } \\
\text { Saliva }\end{array}$ & $\begin{array}{l}\text { TOS and OSI showed no difference } \\
\text { between groups in serum after } \\
\text { therapy; } \\
\uparrow \text { TAC of MS ChP patients before } \\
\text { treatment, but } \downarrow \text { after therapy in } \\
\text { serum; } \downarrow \text { OSI and } \uparrow \text { TAC in both } \\
\text { groups after treatment in saliva }\end{array}$ & Torumtay et al., 2016 \\
\hline NST & $\begin{array}{l}\text { Once per } \\
\text { week } / 1 \\
\text { month }\end{array}$ & $22 \mathrm{ChP}$ patients & None & Saliva & $\begin{array}{l}\uparrow \text { SOD in patients with low dental } \\
\text { visits after NST; } \uparrow \text { TAC in patients with } \\
\text { regular dental visits after therapy }\end{array}$ & Yang et al., 2014 \\
\hline $\begin{array}{l}\text { NST with dietary } \\
\text { intervention }\end{array}$ & $\begin{array}{l}3 \text { visits } / 6 \\
\text { months }\end{array}$ & $\begin{array}{l}37 \text { ChP patients } \\
\text { (19 without intervention; } \\
18 \text { with intervention) }\end{array}$ & None & $\begin{array}{l}\text { Plasma } \\
\text { Saliva }\end{array}$ & $\begin{array}{l}\uparrow \text { TAC after dietary intervention in } \\
\text { plasma; no differences in periodontal } \\
\text { clinical parameters after dietary } \\
\text { intervention }\end{array}$ & Zare Javid et al., 2014 \\
\hline
\end{tabular}

ChP, chronic periodontitis; SH, systematically healthy; PH, periodontal healthy; NST, non-surgical treatment; ST, surgical treatment; T1DM, type 1 diabetes mellitus; T2DM, type 2 diabetes mellitus; FMF, familial Mediterranean fever; MS, metabolic syndrome; GCF, gingival crevicular fluid; TAC, total antioxidant capacity; TBARS, thiobarbituric acid reacting substances; 8HOdG, 8-hydroxydeoxyguanosine; GPX, glutathione peroxidase; GSH, reduced glutathione; MDA, malondialdehyde; TOS, total oxidant status; SOD, superoxid dismutase; OSI, oxidative stress index; IL-1Ss, salivary interleukin 1beta; ROM, reactive oxygen metabolites; 4-HNE, 4-hydroxy-2-nonenal; hsCRP, high-sensitivity C-reactive protein; d-8-iso, d-8-iso prostaglandin F2a; MMP-2, matrix metalloproteinase 2; MMP-9, matrix metalloproteinase 9; LDL, low density lipoprotein; ALB, albumin; UA, uric acid; CAT, catalase; CRP, C-reactive protein; PI, plaque index; Gl, gingival bleeding index; PPD, probing pocket depth; CAL, clinical attachment level; TNF-alpha, tumor necrosis factor alpha; cGMP, L-arginine-nitric oxide (NO)-cyclic guanosine monophosphate. 
divided into smokers and non-smokers. While smokers with periodontitis displayed highest malondialdehyde concentration and highest glutathione peroxidase activity along with lowest total antioxidant capacity in saliva. The non-surxgical treatment helped to normalize the values regardless of the smoking status (Guentsch et al., 2008). Several other trials confirmed the consistency of these findings (Chapple et al., 2007a; Abou Sulaiman and Shehadeh, 2010; Hendek et al., 2015). On the other hand, a severe systemic condition such as type 2 diabetes may lead to inefficiency of non-surgical therapies to improve the periodontal status or oxidative stress (Koromantzos et al., 2012). In general, most of the studies clearly show an improvement of oxidative damage after standard treatment of periodontitis. The studies, however, vary greatly regarding sample types, markers measured, and most cohorts were very small and highly variable. Thus, making relevant conclusions or recommendations for the clinical dentistry is difficult, if not impossible. Future research efforts should focus on the lack of uniformity and standardization as well as on the issue of the low informative value of small patient cohorts.

Although the causality of the association between oxidative stress and periodontitis is everything but clear, some clinical studies already tested antioxidants in periodontitis. One small, placebo controlled, randomized, and double-blind study showed, that single application of lycopene gel to periodontitis patients improved clinical attachment and decreased oxidative stress in gingival crevicular fluid (Chandra et al., 2013). Nevertheless, a published systematic review on antioxidant treatment of periodontitis revealed that a consistent effect in randomized clinical trials was found only for lipophile antioxidants such as lycopene and vitamin E, but not for hydrophile antioxidants such as vitamin C (Muniz et al., 2015). This might be related to the vulnerability of lipids to oxidative damage, but also to mitochondria as the site of effect of some antioxidants. Interestingly, antioxidants targeting directly mitochondria have been shown to be effective in decreasing inflammatory activity and organ damage in animal model of sepsis (Lowes et al., 2013).

\section{ANIMAL EXPERIMENTS}

The high number of observational and interventional studies analyzing the association between oxidative stress and periodontitis indicates that there are many open questions that cannot be answered by more and more clinical studies. Many of the questions need controlled conditions in experiments. The number of animal experiments analyzing the role oxidative stress in periodontitis is small, but it increases. Periodontitis is mostly induced by ligature placement around the first molars of the animals or local injection of periodontal pathogens or their toxins (Genco et al., 1998; Fine, 2009; Oz and Puleo, 2011). In such a rat model, it was shown that periodontitis leads to an increased production of reactive oxygen species and markers of oxidative damage (Ekuni et al., 2010). In addition, oxidative stress induced by periodontitis seems to be associated with the dynamics and severity of the periodontal inflammation (Bosca et al., 2016).

Some animal experiments focus on the distant effects of periodontitis that seem to be mediated by oxidative stress. It was shown that mitochondrial DNA is oxidatively modified in the liver, kidney, heart, and brain of rats with induced periodontitis (Tomofuji et al., 2011). Another similar experiment by the same group has shown that periodontitis might worsen ethanolinduced liver damage (Tomofuji et al., 2008). The oxidative damage to the heart, but also endothelial dysfunction and resulting atherosclerosis induced by experimental periodontitis can be prevented by antioxidant treatment (Ekuni et al., 2009; Ozdem et al., 2017; Saito et al., 2017). A majority of the published experiments focus on the use of antioxidants such as vitamin C (Tomofuji et al., 2009b), N-acetylcysteine (Toker et al., 2009), or resveratrol (Tamaki et al., 2014a), but also drugs with an antioxidant activity beyond their main mechanism of action (de Araujo Junior et al., 2013; Culic et al., 2014; Oktay et al., 2015). Dietary interventions have also been investigated-high cholesterol diet seems to worsen periodontitis (Tomofuji et al., 2006). On contrary, the phytoestrogen genistein and cacaoenriched diet was shown to be protective against periodontal damage and oxidative stress induced by periodontitis in mice and rats, respectively (Tomofuji et al., 2009a; Bhattarai et al., 2017). The most promising candidate drug at least according to animal experiments is melatonin. This amphiphile molecule has an optimal distribution in the tissues and can, thus, reach the periodontal tissues even after systemic administration (Köse et al., 2017). Of special clinical relevance is the induction of periodontitis in diabetic rats since periodontitis is a common complication of diabetes in humans. Melatonin was able to prevent alveolar bone loss also in this experimental model (Kose et al., 2016). However, regarding the mechanism of action, it is not clear whether the protective effect of melatonin is due to its direct antioxidant characteristics or due to its immunomodulatory effects that might reduce oxidative stress indirectly (Kara et al., 2013). This uncertainty is not specific for melatonin. Any antioxidant might affect the immune response and, thus, have anti-inflammatory properties. Beyond established systemic antioxidants novel approaches with a local periodontal application are tested (Saita et al., 2016). Experimental tools such as genetically engineered mice that produce luciferase under the regulation of transcription factors related to oxidative stress and antioxidant response have been developed and might greatly improve our understanding of the role of oxidative stress in periodontitis (Kataoka et al., 2016). The new treatment options together with new and improved models could be very helpful in the fight against this widespread and serious disease.

\section{CONCLUSION}

The role of oxidative stress in periodontitis is not clear despite decades of research. Numerous studies have been published showing the potential of oxidative stress markers for screening, diagnosis or monitoring of the disease, but none is in routine clinical use. Similarly, animal experiments, as well as most of 
the interventional studies in patients, indicate that antioxidant treatment should be effective in the therapy of periodontitis, but no such treatment has been approved. The lack of translation could be either due to the lack of strong evidence for the clinical usefulness or due to obstacles in the application of the results including the low or absent commercial interest from major stakeholders. From a research perspective, an important issue is the lack of specificity-both, in diagnostics and treatment. Not even the source of free radical production is clear. While some studies point toward neutrophils (Katsuragi et al., 2003), others show that bacteria actively producing reactive oxygen species might contribute to oxidative stress in periodontitis (Huycke et al., 2002; Vlkova and Celec, 2009). It is of crucial importance that the number of conducted animal experiments in this field is increasing, especially of those focusing on the dynamics of oxidative stress during disease progression. The antioxidant treatment might be effective only in a subset of patients during a

\section{REFERENCES}

Abou Sulaiman, A. E., and Shehadeh, R. M. (2010). Assessment of total antioxidant capacity and the use of vitamin $\mathrm{C}$ in the treatment of non-smokers with chronic periodontitis. J. Periodontol. 81, 1547-1554. doi: 10.1902/jop.2010.100173

Acquier, A. B., De Couto Pita, A. K., Busch, L., and Sánchez, G. A. (2017). Parameters of oxidative stress in saliva from patients with aggressive and chronic periodontitis. Redox Rep. 22, 119-126. doi: 10.1080/13510002.2016.1198104

Ahmadi-Motamayel, F., Goodarzi, M. T., Jamshidi, Z., and Kebriaei, R. (2017). Evaluation of salivary and serum antioxidant and oxidative stress statuses in patients with chronic periodontitis: a case-control study. Front. Physiol. 8:189. doi: 10.3389/fphys.2017.00189

Akalin, F. A., Baltacioglu, E., Alver, A., and Karabulut, E. (2009). Total antioxidant capacity and superoxide dismutase activity levels in serum and gingival crevicular fluid in pregnant women with chronic periodontitis. J. Periodontol. 80, 457-467. doi: 10.1902/jop.2009.080218

Allen, E. M., Matthews, J. B., O' Halloran, D. J., Griffiths, H. R., and Chapple, I. L. (2011). Oxidative and inflammatory status in Type 2 diabetes patients with periodontitis. J. Clin. Periodontol. 38, 894-901. doi: 10.1111/j.1600-051X.2011.01764.x

Almerich-Silla, J. M., Montiel-Company, J. M., Pastor, S., Serrano, F., Puig-Silla, M., and Dasí, F. (2015). Oxidative stress parameters in saliva and its association with periodontal disease and types of bacteria. Dis. Markers 2015:653537. doi: $10.1155 / 2015 / 653537$

Alpha-Tocopherol, Beta Carotene Cancer Prevention Study Group. (1994). The effect of vitamin $\mathrm{E}$ and beta carotene on the incidence of lung cancer and other cancers in male smokers. N. Engl. J. Med. 330, 1029-1035. doi: 10.1056/NEJM199404143301501

Ambati, M., Rani, K. R., Reddy, P. V., Suryaprasanna, J., Dasari, R., and Gireddy, H. (2017). Evaluation of oxidative stress in chronic periodontitis patients following systemic antioxidant supplementation: a clinical and biochemical study. J. Nat. Sci. Biol. Med. 8, 99-103. doi: 10.4103/0976-9668.198366

Aral, C. A., Nalbantoglu Ö, O., Nur, B. G., Altunsoy, M., and Aral, K. (2017). Metabolic control and periodontal treatment decreases elevated oxidative stress in the early phases of type 1 diabetes onset. Arch. Oral Biol. 82, 115-120. doi: 10.1016/j.archoralbio.2017.06.009

Arana, C., Moreno-Fernández, A. M., Gómez-Moreno, G., Morales-Portillo, C., Serrano-Olmedo, I., de la Cuesta Mayor, M. C., et al. (2017). Increased salivary oxidative stress parameters in patients with type 2 diabetes: relation with periodontal disease. Endocrinol. Diabetes Nutr. 64, 258-264. doi: 10.1016/j.endinu.2017.03.005

Arora, N., Avula, H., and Avula, J. K. (2013). The adjunctive use of systemic antioxidant therapy (lycopene) in nonsurgical treatment of chronic specific stage of periodontitis. The shift from pure observations to interventions and animal experiments that can be followed in the published literature in the recent years is highly positive and should bring this field of research closer to true clinical applications despite chronic lack of financial support and human resources.

\section{AUTHOR CONTRIBUTIONS}

L'T has analyzed the data from the literature, prepared tables, and drafted the manuscript; PC has designed the review, conducted the literature search, and drafted the manuscript.

\section{FUNDING}

The authors are supported from the European Operational Program funded by the ERDF (project ITMS: 26240120027). periodontitis: a short-term evaluation. Quintessence Int. 44, 395-405. doi: 10.3290/j.qi.a29188

Atabay, V. E., Lutfioglu, M., Avci, B., Sakallioglu, E. E., and Aydogdu, A. (2017). Obesity and oxidative stress in patients with different periodontal status: a case-control study. J. Periodont. Res. 52, 51-60. doi: 10.1111/jre.12368

Azzi, A. (2017). Antioxidants: wonder drugs or quackery? Biofactors. doi: 10.1002/biof.1388. [Epub ahead of print].

Baltacioglu, E., Akalin, F. A., Alver, A., Balaban, F., Unsal, M., and Karabulut, E. (2006). Total antioxidant capacity and superoxide dismutase activity levels in serum and gingival crevicular fluid in post-menopausal women with chronic periodontitis. J. Clin. Periodontol. 33, 385-392. doi: 10.1111/j.1600-051X.2006.00923.x

Baltacioglu, E., Yuva, P., Aydin, G., Alver, A., Kahraman, C., Karabulut, E., et al. (2014). Lipid peroxidation levels and total oxidant/antioxidant status in serum and saliva from patients with chronic and aggressive periodontitis. oxidative stress index: a new biomarker for periodontal disease? J. Periodontol. 85, 1432-1441. doi: 10.1902/jop.2014.130654

Banasová, L., Kamodyová, N., Janšáková, K., Tóthová, L., Stanko, P., Turna, J., et al. (2015). Salivary DNA and markers of oxidative stress in patients with chronic periodontitis. Clin. Oral Investig. 19, 201-207. doi: 10.1007/s00784-0141236-Z

Bhattarai, G., Poudel, S. B., Kook, S. H., and Lee, J. C. (2017). Anti-inflammatory, anti-osteoclastic, and antioxidant activities of genistein protect against alveolar bone loss and periodontal tissue degradation in a mouse model of periodontitis. J. Biomed. Mater. Res. A 105, 2510-2521. doi: 10.1002/jbm.a.36109

Biasi, D., Bambara, L. M., Carletto, A., Caramaschi, P., Andrioli, G., Urbani, G., et al. (1999). Neutrophil migration, oxidative metabolism and adhesion in early onset periodontitis. J. Clin. Periodontol. 26, 563-568. doi: 10.1034/j.1600-051X.1999.260901.x

Bjelakovic, G., Nikolova, D., Gluud, L. L., Simonetti, R. G., and Gluud, C. (2007). Mortality in randomized trials of antioxidant supplements for primary and secondary prevention: systematic review and meta-analysis. JAMA 297, 842-857. doi: 10.1001/jama.297.8.842

Bjelakovic, G., Nikolova, D., Gluud, L. L., Simonetti, R. G., and Gluud, C. (2012). Antioxidant supplements for prevention of mortality in healthy participants and patients with various diseases. Cochrane Database Syst. Rev. Cd007176. doi: 10.1002/14651858.CD007176.pub2

Borges, I. Jr., Moreira, E. A., Filho, D. W., de Oliveira, T. B., da Silva, M. B., and Fröde, T. S. (2007). Proinflammatory and oxidative stress markers in patients with periodontal disease. Mediators Inflamm. 2007:45794. doi: 10.1155/2007/45794

Boșca, A. B., Miclăuş, V., Ilea, A., Câmpian, R. S., Rus, V., Ruxanda, F., et al. (2016). Role of nitro-oxidative stress in the pathogenesis of experimental rat periodontitis. Clujul. Med. 89, 150-159. doi: 10.15386/cjmed-529 
Bostanci, V., Toker, H., Senel, S., Ozdemir, H., and Aydin, H. (2014). Effect of chronic periodontitis on serum and gingival crevicular fluid oxidant and antioxidant status in patients with familial mediterranean fever before and after periodontal treatment. J. Periodontol. 85, 706-712. doi: 10.1902/jop.2013.130230

Brock, G. R., Butterworth, C. J., Matthews, J. B., and Chapple, I. L. (2004). Local and systemic total antioxidant capacity in periodontitis and health. J. Clin. Periodontol. 31, 515-521. doi: 10.1111/j.1600-051X.2004.00509.x

Canakçi, C. F., Canakçi, V., Tatar, A., Eltas, A., Sezer, U., Ciçek, Y., et al. (2009). Increased salivary level of 8-hydroxydeoxyguanosine is a marker of premature oxidative mitochondrial DNA damage in gingival tissue of patients with periodontitis. Arch. Immunol. Ther. Exp. 57, 205-211. doi: 10.1007/s00005-009-0026-9

Canakçi, C. F., Tatar, A., Canakçi, V., Cicek, Y., Oztas, S., and Orbak, R. (2006). New evidence of premature oxidative DNA damage: mitochondrial DNA deletion in gingival tissue of patients with periodontitis. J. Periodontol. 77, 1894-1900. doi: 10.1902/jop.2006.060108

Canakci, V., Yildirim, A., Canakci, C. F., Eltas, A., Cicek, Y., and Canakci, H. (2007). Total antioxidant capacity and antioxidant enzymes in serum, saliva, and gingival crevicular fluid of preeclamptic women with and without periodontal disease. J. Periodontol. 78, 1602-1611. doi: 10.1902/jop.2007.060469

Chandra, R. V., Sailaja, S., and Reddy, A. A. (2017). Estimation of tissue and crevicular fluid oxidative stress marker in premenopausal, perimenopausal and postmenopausal women with chronic periodontitis. Gerodontology 34, 382-389. doi: 10.1111/ger.12279

Chandra, R. V., Srinivas, G., Reddy, A. A., Reddy, B. H., Reddy, C., Nagarajan, S., et al. (2013). Locally delivered antioxidant gel as an adjunct to nonsurgical therapy improves measures of oxidative stress and periodontal disease. J. Periodontal Implant Sci. 43, 121-129. doi: 10.5051/jpis.2013.43.3.121

Chapple, I. L. (1997). Reactive oxygen species and antioxidants in inflammatory diseases. J. Clin. Periodontol. 24, 287-296. doi: 10.1111/j.1600-051X.1997.tb00760.x

Chapple, I. L., Brock, G. R., Milward, M. R., Ling, N., and Matthews, J. B. (2007a). Compromised GCF total antioxidant capacity in periodontitis: cause or effect? J. Clin. Periodontol. 34, 103-110. doi: 10.1111/j.1600-051X.2006.01029.x

Chapple, I. L., Brock, G., Eftimiadi, C., and Matthews, J. B. (2002). Glutathione in gingival crevicular fluid and its relation to local antioxidant capacity in periodontal health and disease. Mol. Pathol. 55, 367-373. doi: $10.1136 / \mathrm{mp} .55 .6 .367$

Chapple, I. L., Milward, M. R., and Dietrich, T. (2007b). The prevalence of inflammatory periodontitis is negatively associated with serum antioxidant concentrations. J. Nutr. 137, 657-664.

Coulter, I. D., Hardy, M. L., Morton, S. C., Hilton, L. G., Tu, W., Valentine, D., et al. (2006). Antioxidants vitamin C and vitamin e for the prevention and treatment of cancer. J. Gen. Intern. Med. 21, 735-744. doi: 10.1111/j.1525-1497.2006.00483.x

Culic, C., Parvu, A. E., Alb, S. F., Alb, C., and Pop, A. (2014). Effect of Cimetidine on nitro-oxidative stress in a rat model of periodontitis. Clujul. Med. 87, 177-181. doi: 10.15386/cjmed-273

D’Aiuto, F., Nibali, L., Parkar, M., Patel, K., Suvan, J., and Donos, N. (2010). Oxidative stress, systemic inflammation, and severe periodontitis. J. Dent. Res. 89, 1241-1246. doi: 10.1177/0022034510375830

de Araújo Júnior, R. F., Souza, T. O., de Moura, L. M., Torres, K. P., de Souza, L. B., Alves Mdo, S., et al. (2013). Atorvastatin decreases bone loss, inflammation and oxidative stress in experimental periodontitis. PLoS ONE 8:e75322. doi: 10.1371/journal.pone.0075322

Diab-Ladki, R., Pellat, B., and Chahine, R. (2003). Decrease in the total antioxidant activity of saliva in patients with periodontal diseases. Clin. Oral Investig. 7, 103-107. doi: 10.1007/s00784-003-0208-5

Domínguez, A., Gómez, C., García-Kass, A. I., and García-Nuñez, J. A. (2010). IL-1beta, TNF-alpha, total antioxidative status and microbiological findings in chronic periodontitis treated with fluorescence-controlled Er:YAG laser radiation. Lasers Surg. Med. 42, 24-31. doi: 10.1002/1sm.20873

Duarte, P. M., Napimoga, M. H., Fagnani, E. C., Santos, V. R., Bastos, M. F., Ribeiro, F. V., et al. (2012). The expression of antioxidant enzymes in the gingivae of type 2 diabetics with chronic periodontitis. Arch. Oral Biol. 57, 161-168. doi: 10.1016/j.archoralbio.2011.08.007
Ekuni, D., Endo, Y., Irie, K., Azuma, T., Tamaki, N., Tomofuji, T., et al. (2010). Imbalance of oxidative/anti-oxidative status induced by periodontitis is involved in apoptosis of rat submandibular glands. Arch. Oral Biol. 55, 170-176. doi: 10.1016/j.archoralbio.2009.11.013

Ekuni, D., Tomofuji, T., Sanbe, T., Irie, K., Azuma, T., Maruyama, T., et al. (2009). Vitamin $\mathrm{C}$ intake attenuates the degree of experimental atherosclerosis induced by periodontitis in the rat by decreasing oxidative stress. Arch. Oral Biol. 54, 495-502. doi: 10.1016/j.archoralbio.2009.02.006

Esen, C., Alkan, B. A., Kirnap, M., Akgül, O., Işikoglu, S., and Erel, O. (2012). The effects of chronic periodontitis and rheumatoid arthritis on serum and gingival crevicular fluid total antioxidant/oxidant status and oxidative stress index. J. Periodontol. 83, 773-779. doi: 10.1902/jop.2011.110420

Espinosa-Diez, C., Miguel, V., Mennerich, D., Kietzmann, T., Sánchez-Pérez, P., Cadenas, S., et al. (2015). Antioxidant responses and cellular adjustments to oxidative stress. Redox Biol. 6, 183-197. doi: 10.1016/j.redox.2015.07.008

Fentoglu Ö, O., Kirzioglu, F. Y., Bulut, M. T., Kumbul Doguç, D., Kulaç, E., Önder, C., et al. (2015). Evaluation of lipid peroxidation and oxidative DNA damage in patients with periodontitis and hyperlipidemia. J. Periodontol. 86, 682-688. doi: 10.1902/jop.2015.140561

Fine, D. H. (2009). Of mice and men: animal models of human periodontal disease. J. Clin. Periodontol. 36, 913-914. doi: 10.1111/j.1600-051X.2009.01456.x

Finkel, T. (2011). Signal transduction by reactive oxygen species. J. Cell Biol. 194, 7-15. doi: $10.1083 /$ jcb. 201102095

Finkel, T., and Holbrook, N. J. (2000). Oxidants, oxidative stress and the biology of ageing. Nature 408, 239-247. doi: 10.1038/35041687

Frijhoff, J., Winyard, P. G., Zarkovic, N., Davies, S. S., Stocker, R., Cheng, D., et al. (2015). Clinical relevance of biomarkers of oxidative stress. Antioxid. Redox Signal. 23, 1144-1170. doi: 10.1089/ars.2015.6317

Genco, C. A., Van Dyke, T., and Amar, S. (1998). Animal models for Porphyromonas gingivalis-mediated periodontal disease. Trends Microbiol. 6, 444-449. doi: 10.1016/S0966-842X(98)01363-8

Gomes, C., Martinho, F. C., Barbosa, D. S., Antunes, L. S., Póvoa, H. C. C., Baltus, T. H. L., et al. (2017). Increased root canal endotoxin levels are associated with chronic apical periodontitis, increased oxidative and nitrosative stress, major depression, severity of depression, and a lowered quality of life. Mol. Neurobiol. doi: 10.1007/s12035-017-0545-z. [Epub ahead of print].

Guentsch, A., Preshaw, P., Bremer-Streck, S., Klinger, G., Glockmann, E., and Sigusch, B. (2008). Lipid peroxidation and antioxidant activity in saliva of periodontitis patients: effect of smoking and periodontal treatment. Clin. Oral Investig. 12, 345-352. doi: 10.1007/s00784-008-0202-z

Gümüş, P., Buduneli, N., Cetinkalp, S., Hawkins, S. I., Renaud, D., Kinane, D. F., et al. (2009). Salivary antioxidants in patients with type 1 or 2 diabetes and inflammatory periodontal disease: a case-control study. J. Periodontol. 80, 1440-1446. doi: 10.1902/jop.2009.090159

Gümüș, P., Emingil, G., Öztürk, V. O., Belibasakis, G. N., and Bostanci, N. (2015). Oxidative stress markers in saliva and periodontal disease status: modulation during pregnancy and postpartum. BMC Infect. Dis. 15:261. doi: 10.1186/s12879-015-1003-z

Harman, D. (1956). Aging: a theory based on free radical and radiation chemistry. J. Gerontol. 11, 298-300. doi: 10.1093/geronj/11.3.298

Hendek, M. K., Erdemir, E. O., Kisa, U., and Ozcan, G. (2015). Effect of initial periodontal therapy on oxidative stress markers in gingival crevicular fluid, saliva, and serum in smokers and non-smokers with chronic periodontitis. $J$. Periodontol. 86, 273-282. doi: 10.1902/jop.2014.140338

Hickman, M. A., Boggess, K. A., Moss, K. L., Beck, J. D., and Offenbacher, S. (2011). Maternal periodontal disease is associated with oxidative stress during pregnancy. Am. J. Perinatol. 28, 247-252. doi: 10.1055/s-0030-12 68706

Huang, Y., Zhu, M., Li, Z., Sa, R., Chu, Q., Zhang, Q., et al. (2014). Mass spectrometry-based metabolomic profiling identifies alterations in salivary redox status and fatty acid metabolism in response to inflammation and oxidative stress in periodontal disease. Free Radic. Biol. Med. 70, 223-232. doi: 10.1016/j.freeradbiomed.2014.02.024

Huycke, M. M., Abrams, V., and Moore, D. R. (2002). Enterococcus faecalis produces extracellular superoxide and hydrogen peroxide that damages colonic epithelial cell DNA. Carcinogenesis 23, 529-536. doi: 10.1093/carcin/23.3.529

Kara, A., Akman, S., Ozkanlar, S., Tozoglu, U., Kalkan, Y., Canakci, C. F., et al. (2013). Immune modulatory and antioxidant effects of melatonin 
in experimental periodontitis in rats. Free Radic. Biol. Med. 55, 21-26. doi: 10.1016/j.freeradbiomed.2012.11.002

Kataoka, K., Ekuni, D., Tomofuji, T., Irie, K., Kunitomo, M., Uchida, Y., et al. (2016). Visualization of oxidative stress induced by experimental periodontitis in keap1-dependent oxidative stress detector-luciferase mice. Int. J. Mol. Sci. 17:1907. doi: 10.3390/ijms17111907

Katsuragi, H., Ohtake, M., Kurasawa, I., and Saito, K. (2003). Intracellular production and extracellular release of oxygen radicals by PMNs and oxidative stress on PMNs during phagocytosis of periodontopathic bacteria. Odontology 91, 13-18. doi: 10.1007/s10266-003-0022-1

Khocht, A., Russell, B., Cannon, J. G., Turner, B., and Janal, M. (2014). Oxidative burst intensity of peripheral phagocytic cells and periodontitis in down syndrome. J. Periodont. Res. 49, 29-35. doi: 10.1111/jre.12075

Kim, S. C., Kim, O. S., Kim, O. J., Kim, Y. J., and Chung, H. J. (2010). Antioxidant profile of whole saliva after scaling and root planing in periodontal disease. J. Periodont. Implant Sci. 40, 164-171. doi: 10.5051/jpis.2010.40.4.164

Kimura, S., Yonemura, T., and Kaya, H. (1993). Increased oxidative product formation by peripheral blood polymorphonuclear leukocytes in human periodontal diseases. J. Periodontal Res. 28, 197-203. doi: 10.1111/j.1600-0765.1993.tb01069.x

Kinane, D. F., Preshaw, P. M., Loos, B. G., and Working Group 2 of Seventh European Workshop on Periodontology. (2011). Hostresponse: understanding the cellular and molecular mechanisms of host-microbial interactions-consensus of the seventh European workshop on periodontology. J. Clin. Periodontol. 38(Suppl. 11), 44-48. doi: 10.1111/j.1600-051X.2010.01682.x

Kinane, D. F., Stathopoulou, P. G., and Papapanou, P. N. (2017). Periodontal diseases. Nat. Rev. Dis. Primers 3:17038. doi: 10.1038/nrdp.2017.38

Konopka, T., Król, K., Kopeć, W., and Gerber, H. (2007). Total antioxidant status and 8-hydroxy-2'-deoxyguanosine levels in gingival and peripheral blood of periodontitis patients. Arch. Immunol. Ther. Exp. 55, 417-422. doi: 10.1007/s00005-007-0047-1

Kopáni, M., Celec, P., Danisovic, L., Michalka, P., and Biró, C. (2006). Oxidative stress and electron spin resonance. Clin. Chim. Acta 364, 61-66. doi: 10.1016/j.cca.2005.05.016

Koromantzos, P. A., Makrilakis, K., Dereka, X., Offenbacher, S., Katsilambros, N., Vrotsos, I. A., et al. (2012). Effect of non-surgical periodontal therapy on Creactive protein, oxidative stress, and matrix metalloproteinase (MMP)-9 and MMP-2 levels in patients with type 2 diabetes: a randomized controlled study. J. Periodontol. 83, 3-10. doi: 10.1902/jop.2011.110148

Kose, O., Arabaci, T., Kara, A., Yemenoglu, H., Kermen, E., Kizildag, A., et al. (2016). Effects of melatonin on oxidative stress index and alveolar bone loss in diabetic rats with periodontitis. J. Periodontol. 87, e82-e90. doi: 10.1902/jop.2016.150541

Köse, O., Arabaci, T., Kizildag, A., Erdemci, B., Özkal Eminoglu, D., Gedikli, S., et al. (2017). Melatonin prevents radiation-induced oxidative stress and periodontal tissue breakdown in irradiated rats with experimental periodontitis. J. Periodont. Res. 52, 438-446. doi: 10.1111/jre.12409

Laine, M. L., Crielaard, W., and Loos, B. G. (2012). Genetic susceptibility to periodontitis. Periodontol 2000 58, 37-68. doi: 10.1111/j.1600-0757.2011.00415.x

Linden, G. J., McClean, K. M., Woodside, J. V., Patterson, C. C., Evans, A., Young, I. S., et al. (2009). Antioxidants and periodontitis in 60-70-year-old men. J. Clin. Periodontol. 36, 843-849. doi: 10.1111/j.1600-051X.2009.01468.x

Liu, Z., Liu, Y., Song, Y., Zhang, X., Wang, S., and Wang, Z. (2014). Systemic oxidative stress biomarkers in chronic periodontitis: a meta-analysis. Dis. Markers 2014:931083. doi: 10.1155/2014/931083

Loesche, W. J., Robinson, J. P., Flynn, M., Hudson, J. L., and Duque, R. E. (1988). Reduced oxidative function in gingival crevicular neutrophils in periodontal disease. Infect. Immun. 56, 156-160.

Lowes, D. A., Webster, N. R., Murphy, M. P., and Galley, H. F. (2013). Antioxidants that protect mitochondria reduce interleukin- 6 and oxidative stress, improve mitochondrial function, and reduce biochemical markers of organ dysfunction in a rat model of acute sepsis. Br. J. Anaesth. 110, 472-480. doi: 10.1093/bja/aes577

Masi, S., Salpea, K. D., Li, K., Parkar, M., Nibali, L., Donos, N., et al. (2011). Oxidative stress, chronic inflammation, and telomere length in patients with periodontitis. Free Radic. Biol. Med. 50, 730-735. doi: 10.1016/j.freeradbiomed.2010.12.031

Mathur, A., Mathur, L., Manohar, B., Mathur, H., Shankarapillai, R., Shetty, N., et al. (2013). Antioxidant therapy as monotherapy or as an adjunct to treatment of periodontal diseases. J. Indian Soc. Periodontol. 17, 21-24. doi: 10.4103/0972-124X.107469

Mendoza-Núñez, V. M., Hernández-Monjaraz, B., Santiago-Osorio, E., Betancourt-Rule, J. M., and Ruiz-Ramos, M. (2014). Tai Chi exercise increases SOD activity and total antioxidant status in saliva and is linked to an improvement of periodontal disease in the elderly. Oxid. Med. Cell. Longev. 2014:603853. doi: 10.1155/2014/603853

Miricescu, D., Totan, A., Calenic, B., Mocanu, B., Didilescu, A., Mohora, M., et al. (2014). Salivary biomarkers: relationship between oxidative stress and alveolar bone loss in chronic periodontitis. Acta Odontol. Scand. 72, 42-47. doi: 10.3109/00016357.2013.795659

Monea, A., Mezei, T., Popsor, S., and Monea, M. (2014). Oxidative stress: a link between diabetes mellitus and periodontal disease. Int. J. Endocrinol. 2014:917631. doi: 10.1155/2014/917631

Muniz, F. W., Nogueira, S. B., Mendes, F. L., Rosing, C. K., Moreira, M. M., de Andrade, G. M., et al. (2015). The impact of antioxidant agents complimentary to periodontal therapy on oxidative stress and periodontal outcomes: a systematic review. Arch. Oral Biol. 60, 1203-1214. doi: 10.1016/j.archoralbio.2015.05.007

Myung, S. K., Ju, W., Cho, B., Oh, S. W., Park, S. M., Koo, B. K., et al. (2013). Efficacy of vitamin and antioxidant supplements in prevention of cardiovascular disease: systematic review and meta-analysis of randomised controlled trials. BMJ 346:f10. doi: 10.1136/bmj.f10

Nguyen, T. T., Ngo, L. Q., Promsudthi, A., and Surarit, R. (2016). Salivary oxidative stress biomarkers in chronic periodontitis and acute coronary syndrome. Clin. Oral Investig. 21, 2345-2353. doi: 10.1007/s00784-016-2029-3

Nibali, L., Rizzo, M., Li Volti, G., D’Aiuto, F., Giglio, R. V., Barbagallo, I., et al. (2015). Lipid subclasses profiles and oxidative stress in aggressive periodontitis before and after treatment. J. Periodont. Res. 50, 890-896. doi: 10.1111/jre.12283

Niki, E. (2016). Oxidative stress and antioxidants: distress or eustress? Arch. Biochem. Biophys. 595, 19-24. doi: 10.1016/j.abb.2015. 11.017

Novakovic, N., Todorovic, T., Rakic, M., Milinkovic, I., Dozic, I., Jankovic, S., et al. (2014). Salivary antioxidants as periodontal biomarkers in evaluation of tissue status and treatment outcome. J. Periodont. Res. 49, 129-136. doi: $10.1111 /$ jre. 12088

Oktay, S., Chukkapalli, S. S., Rivera-Kweh, M. F., Velsko, I. M., Holliday, L. S., and Kesavalu, L. (2015). Periodontitis in rats induces systemic oxidative stress that is controlled by bone-targeted antiresorptives. J. Periodontol. 86, 137-145. doi: 10.1902/jop.2014.140302

Önder, C., Kurgan, S., Altingöz, S. M., Bagiș, N., Uyanik, M., Serdar, M. A., et al. (2017). Impact of non-surgical periodontal therapy on saliva and serum levels of markers of oxidative stress. Clin. Oral Investig. 21, 1961-1969. doi: 10.1007/s00784-016-1984-z

Oz, H. S., and Puleo, D. A. (2011). Animal models for periodontal disease. J. Biomed. Biotechnol. 2011:754857. doi: 10.1155/2011/754857

Özdem, M., Kirzioglu, F. Y., Yilmaz, H. R., Vural, H., Fentoglu, Ö., Uz, E., et al. (2017). Antioxidant effects of melatonin in heart tissue after induction of experimental periodontitis in rats. J. Oral Sci. 59, 23-29. doi: 10.2334/josnusd.16-0034

Panjamurthy, K., Manoharan, S., and Ramachandran, C. R. (2005). Lipid peroxidation and antioxidant status in patients with periodontitis. Cell. Mol. Biol. Lett. 10, 255-264.

Piskounova, E., Agathocleous, M., Murphy, M. M., Hu, Z., Huddlestun, S. E., Zhao, Z., et al. (2015). Oxidative stress inhibits distant metastasis by human melanoma cells. Nature 527, 186-191. doi: 10.1038/nature15726

Raut, C. P., and Sethi, K. S. (2016). Comparative evaluation of co-enzyme Q10 and Melaleuca alternifolia as antioxidant gels in treatment of chronic periodontitis: a clinical study. Contemp. Clin. Dent. 7, 377-381. doi: 10.4103/0976-237X.188572

Rumbold, A. R., Crowther, C. A., Haslam, R. R., Dekker, G. A., and Robinson, J. S. (2006). Vitamins $C$ and $E$ and the risks of preeclampsia and perinatal complications. N. Engl. J. Med. 354, 1796-1806. doi: 10.1056/NEJMoa054186 
Russell, E. G., and Cotter, T. G. (2015). New insight into the role of reactive oxygen species (ROS) in cellular signal-transduction processes. Int. Rev. Cell Mol. Biol. 319, 221-254. doi: 10.1016/bs.ircmb.2015.07.004

Saita, M., Kaneko, J., Sato, T., Takahashi, S. S., Wada-Takahashi, S., Kawamata, R., et al. (2016). Novel antioxidative nanotherapeutics in a rat periodontitis model: Reactive oxygen species scavenging by redox injectable gel suppresses alveolar bone resorption. Biomaterials 76, 292-301. doi: 10.1016/j.biomaterials.2015.10.077

Saito, T., Yamamoto, Y., Feng, G. G., Kazaoka, Y., Fujiwara, Y., and Kinoshita, H. (2017). Lidocaine prevents oxidative stress-induced endothelial dysfunction of the systemic artery in rats with intermittent periodontal inflammation. Anesth. Analg. 124, 2054-2062. doi: 10.1213/ANE.0000000000002102

Sawamoto, Y., Sugano, N., Tanaka, H., and Ito, K. (2005). Detection of periodontopathic bacteria and an oxidative stress marker in saliva from periodontitis patients. Oral Microbiol. Immunol. 20, 216-220. doi: 10.1111/j.1399-302X.2005.00215.x

Sayin, V. I., Ibrahim, M. X., Larsson, E., Nilsson, J. A., Lindahl, P., and Bergo, M. O. (2014). Antioxidants accelerate lung cancer progression in mice. Sci. Transl. Med. 6, 221ra215. doi: 10.1126/scitranslmed.3007653

Sculley, D. V., and Langley-Evans, S. C. (2003). Periodontal disease is associated with lower antioxidant capacity in whole saliva and evidence of increased protein oxidation. Clin. Sci. 105, 167-172. doi: 10.1042/CS20030031

Sesso, H. D., Buring, J. E., Christen, W. G., Kurth, T., Belanger, C., MacFadyen, J., et al. (2008). Vitamins E and C in the prevention of cardiovascular disease in men: the physicians' health study II randomized controlled trial. JAMA 300, 2123-2133. doi: 10.1001/jama.2008.600

Sezer, U., Erciyas, K., Ustün, K., Pehlivan, Y., Senyurt, S. Z., Aksoy, N., et al. (2013). Effect of chronic periodontitis on oxidative status in patients with rheumatoid arthritis. J. Periodontol. 84, 785-792. doi: 10.1902/jop.2012.120179

Sezer, U., Senyurt, S. Z., Gündogar, H., Erciyas, K., Ustun, K., Kimyon, G., et al. (2016). Effect of chronic periodontitis on oxidative status in patients with psoriasis and psoriatic arthritis. J. Periodontol. 87, 557-565. doi: 10.1902/jop.2015.150337

Shapira, L., Borinski, R., Sela, M. N., and Soskolne, A. (1991). Superoxide formation and chemiluminescence of peripheral polymorphonuclear leukocytes in rapidly progressive periodontitis patients. J. Clin. Periodontol. 18, 44-48. doi: 10.1111/j.1600-051X.1991.tb01118.x

Sies, H., Berndt, C., and Jones, D. P. (2017). Oxidative stress. Annu. Rev. Biochem. 86, 715-748. doi: 10.1146/annurev-biochem-061516-045037

Singer, R. E., Moss, K., Kim, S. J., Beck, J. D., and Offenbacher, S. (2015). Oxidative stress and IgG antibody modify periodontitis-CRP association. J. Dent. Res. 94, 1698-1705. doi: 10.1177/0022034515602693

Siqueira, M. A., Fischer, R. G., Pereira, N. R., Martins, M. A., Moss, M. B., MendesRibeiro, A. C., et al. (2013). Effects of non-surgical periodontal treatment on the L-arginine-nitric oxide pathway and oxidative status in platelets. Exp. Biol. Med. 238, 713-722. doi: 10.1177/1535370213480690

Sree, S. L., and Sethupathy, S. (2014). Evaluation of the efficacy of taurine as an antioxidant in the management of patients with chronic periodontitis. Dent. Res. J. 11, 228-233.

Takane, M., Sugano, N., Iwasaki, H., Iwano, Y., Shimizu, N., and Ito, K. (2002). New biomarker evidence of oxidative DNA damage in whole saliva from clinically healthy and periodontally diseased individuals. J. Periodontol. 73, 551-554. doi: 10.1902/jop.2002.73.5.551

Tamaki, N., Cristina Orihuela-Campos, R., Inagaki, Y., Fukui, M., Nagata, T., and Ito, H. O. (2014a). Resveratrol improves oxidative stress and prevents the progression of periodontitis via the activation of the Sirt1/AMPK and the Nrf2/antioxidant defense pathways in a rat periodontitis model. Free Radic. Biol. Med. 75, 222-229. doi: 10.1016/j.freeradbiomed.2014. 07.034

Tamaki, N., Hayashida, H., Fukui, M., Kitamura, M., Kawasaki, K., Nakazato, M., et al. (2014b). Oxidative stress and antibody levels to periodontal bacteria in adults: the Nagasaki Islands study. Oral Dis. 20, e49-e56. doi: 10.1111/odi.12127

Tamaki, N., Tomofuji, T., Ekuni, D., Yamanaka, R., and Morita, M. (2011). Periodontal treatment decreases plasma oxidized LDL level and oxidative stress. Clin. Oral Investig. 15, 953-958. doi: 10.1007/s00784-010$0458-y$
Tamaki, N., Yoshino, F., Fukui, M., Hayashida, H., Yoshida, A., Kitamura, M., et al. (2015). Relationship among salivary antioxidant activity, cytokines, and periodontitis: the Nagasaki Island study. J. Clin. Periodontol. 42, 711-718. doi: $10.1111 /$ jcpe. 12438

Tartaglia, G. M., Gagliano, N., Zarbin, L., Tolomeo, G., and Sforza, C. (2017). Antioxidant capacity of human saliva and periodontal screening assessment in healthy adults. Arch. Oral Biol. 78, 34-38. doi: 10.1016/j.archoralbio.2017.02.003

Thomas, B., Madani, S. M., Prasad, B. R., and Kumari, S. (2014). Comparative evaluation of serum antioxidant levels in periodontally diseased patients: an interventional study. Contemp. Clin. Dent. 5, 340-344. doi: 10.4103/0976-237X.137938

Toker, H., Akpinar, A., Aydin, H., and Poyraz, O. (2012). Influence of smoking on interleukin-lbeta level, oxidant status and antioxidant status in gingival crevicular fluid from chronic periodontitis patients before and after periodontal treatment. J. Periodont. Res. 47, 572-577. doi: 10.1111/j.1600-0765.2012.01468.x

Toker, H., Ozdemir, H., Eren, K., Ozer, H., and Sahin, G. (2009). N-acetylcysteine, a thiol antioxidant, decreases alveolar bone loss in experimental periodontitis in rats. J. Periodontol. 80, 672-678. doi: 10.1902/jop.2009.080509

Tomofuji, T., Azuma, T., Kusano, H., Sanbe, T., Ekuni, D., Tamaki, N., et al. (2006). Oxidative damage of periodontal tissue in the rat periodontitis model: effects of a high-cholesterol diet. FEBS Lett. 580, 3601-3604. doi: 10.1016/j.febslet.2006.05.041

Tomofuji, T., Ekuni, D., Irie, K., Azuma, T., Endo, Y., Tamaki, N., et al. (2009a). Preventive effects of a cocoa-enriched diet on gingival oxidative stress in experimental periodontitis. J. Periodontol. 80, 1799-1808. doi: $10.1902 /$ jop.2009.090270

Tomofuji, T., Ekuni, D., Irie, K., Azuma, T., Tamaki, N., Maruyama, T., et al. (2011). Relationships between periodontal inflammation, lipid peroxide and oxidative damage of multiple organs in rats. Biomed. Res. 32, 343-349. doi: 10.2220/biomedres. 32.343

Tomofuji, T., Ekuni, D., Sanbe, T., Irie, K., Azuma, T., Maruyama, T., et al. (2009b). Effects of vitamin $\mathrm{C}$ intake on gingival oxidative stress in rat periodontitis. Free Radic. Biol. Med. 46, 163-168. doi: 10.1016/j.freeradbiomed.2008.09.040

Tomofuji, T., Sanbe, T., Ekuni, D., Azuma, T., Irie, K., Maruyama, T., et al. (2008). Oxidative damage of rat liver induced by ligature-induced periodontitis and chronic ethanol consumption. Arch. Oral Biol. 53, 1113-1118. doi: 10.1016/j.archoralbio.2008.05.015

Tonguç, M. O., Öztürk, O., Sutcu, R., Ceyhan, B. M., Kilinc, G., Sonmez, Y., et al. (2011). The impact of smoking status on antioxidant enzyme activity and malondialdehyde levels in chronic periodontitis. J. Periodontol. 82, 1320-1328. doi: 10.1902/jop.2011.100618

Torumtay, G., Kirzioglu, F. Y., Ozturk Tonguc, M., Kale, B., Calapoglu, M., and Orhan, H. (2016). Effects of periodontal treatment on inflammation and oxidative stress markers in patients with metabolic syndrome. J. Periodont. Res. 51, 489-498. doi: 10.1111/jre.12328

Tothova, L., Celecova, V., and Celec, P. (2013). Salivary markers of oxidative stress and their relation to periodontal and dental status in children. Dis. Markers 34, 9-15. doi: 10.1155/2013/591765

Trivedi, S., Lal, N., Mahdi, A. A., Mittal, M., Singh, B., and Pandey, S. (2014). Evaluation of antioxidant enzymes activity and malondialdehyde levels in patients with chronic periodontitis and diabetes mellitus. J. Periodontol. 85, 713-720. doi: 10.1902/jop.2013.130066

Villa-Correa, Y. A., Isaza-Guzman, D. M., and Tobon-Arroyave, S. I. (2015). Prognostic value of 8-Hydroxy-2'-Deoxyguanosine and human neutrophil elastase/alpha1-proteinase inhibitor complex as salivary biomarkers of oxidative stress in chronic periodontitis. J. Periodontol. 86, 1260-1267. doi: 10.1902/jop.2015.150293

Vlkova, B., and Celec, P. (2009). Does Enterococcus faecalis contribute to salivary thiobarbituric acid-reacting substances? In Vivo 23, 343-345.

Watson, J. D. (2014). Type 2 diabetes as a redox disease. Lancet 383, 841-843. doi: 10.1016/S0140-6736(13)62365-X

Wei, P. F., Ho, K. Y., Ho, Y. P., Wu, Y. M., Yang, Y. H., and Tsai, C. C. (2004). The investigation of glutathione peroxidase, lactoferrin myeloperoxidase and interleukin-1beta in gingival crevicular fluid: implications for oxidative stress in human periodontal diseases. 
J. Periodont. Res. 39, 287-293. doi: 10.1111/j.1600-0765.2004. 00744.x

Weidinger, A., and Kozlov, A. V. (2015). Biological activities of reactive oxygen and nitrogen species: oxidative stress vs. signal transduction. Biomolecules 5, 472-484. doi: 10.3390/biom5020472

Wolfram, R. M., Budinsky, A. C., Eder, A., Presenhuber, C., Nell, A., Sperr, W., et al. (2006). Salivary isoprostanes indicate increased oxidation injury in periodontitis with additional tobacco abuse. Biofactors 28, 21-31. doi: 10.1002/biof.5520280103

Yang, P. S., Huang, W. C., Chen, S. Y., Chen, C. H., Lee, C. Y., Lin, C. T., et al. (2014). Scaling-stimulated salivary antioxidant changes and oral-health behavior in an evaluation of periodontal treatment outcomes. Sci. World J. 2014:814671. doi: $10.1155 / 2014 / 814671$

Zamora-Perez, A. L., Ortiz-Garcia, Y. M., Lazalde-Ramos, B. P., GuerreroVelazquez, C., Gomez-Meda, B. C., Ramirez-Aguilar, M. A., et al. (2015). Increased micronuclei and nuclear abnormalities in buccal mucosa and oxidative damage in saliva from patients with chronic and aggressive periodontal diseases. J. Periodont. Res. 50, 28-36. doi: 10.1111/jre. 12175
Zare Javid, A., Seal, C. J., Heasman, P., and Moynihan, P. J. (2014). Impact of a customised dietary intervention on antioxidant status, dietary intakes and periodontal indices in patients with adult periodontitis. J. Hum. Nutr. Diet. 27, 523-532. doi: 10.1111/jhn. 12184

Zhang, T., Andrukhov, O., Haririan, H., Muller-Kern, M., Liu, S., Liu, Z., et al. (2015). Total antioxidant capacity and total oxidant status in saliva of periodontitis patients in relation to bacterial load. Front. Cell. Infect. Microbiol. 5:97. doi: $10.3389 /$ fcimb. 2015.00097

Conflict of Interest Statement: The authors declare that the research was conducted in the absence of any commercial or financial relationships that could be construed as a potential conflict of interest.

Copyright $\odot 2017$ Tóthová and Celec. This is an open-access article distributed under the terms of the Creative Commons Attribution License (CC BY). The use, distribution or reproduction in other forums is permitted, provided the original author(s) or licensor are credited and that the original publication in this journal is cited, in accordance with accepted academic practice. No use, distribution or reproduction is permitted which does not comply with these terms. 